\title{
LETHAL OUTCOME IN A HEALTHY MAN INFECTED WITH COVID-19
}

Valentina Opancina $^{1,2}$, Predrag Sazdanovic ${ }^{2,3}$, Dejan Baskic ${ }^{2,4,5}$, Miljan Opancina ${ }^{6,7}$, Nebojsa Zdravkovic $^{8}$ and Radisa Vojinovic ${ }^{1,2}$

${ }^{1}$ University of Kragujevac, Faculty of Medical Sciences, Department of Radiology, Kragujevac, Serbia ${ }^{2}$ Clinical Center "Kragujevac", Kragujevac, Serbia

${ }^{3}$ University of Kragujevac, Faculty of Medical Sciences, Department of Gynecology and Obstetrics, Kragujevac, Serbia ${ }^{4}$ Public Health Institute, Kragujevac, Serbia

${ }^{5}$ University of Kragujevac, Faculty of Medical Sciences, Department of Microbiology and Immunology, Kragujevac, Serbia ${ }^{6}$ University of Kragujevac, Faculty of Medical Sciences, Kragujevac, Serbia ${ }^{7}$ Military Medical Academy, Belgrade, Serbia

${ }^{8}$ University of Kragujevac, Faculty of Medical Sciences, Department of Medical Statistics and Informatics, Kragujevac, Serbia

\section{SMRTNI ISHOD KOD ZDRAVOG MUŠKARCA SA COVID-19 INFEKCIJOM}

\author{
Valentina Opančina ${ }^{1,2}$, Predrag Sazdanović ${ }^{2,3}$, Dejan Baskić2,4,5, Miljan Opančina ${ }^{6,7}$, Nebojša Zdravković ${ }^{8}$ i Radiša Vojinović ${ }^{1,2}$ \\ ${ }^{1}$ Univerzitet u Kragujevcu, Fakultet medicinskih nauka, Katedra za radiologiju, Kragujevac, Srbija \\ ${ }^{2}$ Klinički centar "Kragujevac”, Kragujevac, Srbija \\ ${ }^{3}$ Univerzitet u Kragujevcu, Fakultet medicinskih nauka, Katedra za ginekologiju i akušerstvo, Kragujevac, Srbija \\ ${ }^{4}$ Institut za javno zdravlje, Kragujevac, Serbia \\ ${ }^{5}$ Univerzitet u Kragujevcu, Fakultet medicinskih nauka, Katedra za mikrobiologiju i imunologiju, Kragujevac, Srbija \\ ${ }^{6}$ Univerzitet u Kragujevcu, Fakultet medicinskih nauka, Kragujevac, Srbija \\ ${ }^{7}$ Vojnomedicinska akademija, Beograd, Srbija \\ ${ }^{8}$ Univerzitet u Kragujevcu, Fakultet medicinskih nauka, Katedra za medicinsku statistiku i informatiku, Kragujevac, Srbija
}

\begin{abstract}
COVID-19 is defined as a respiratory infection which is spread by droplets and immediate contact with an infected person. The first case of COVID-19 infection in Serbia was reported on March $6^{\text {th }}, 2020$.

Herein, we present the case of confirmed COVID-19 infection in a previously healthy man, whose three other family members showed mild symptoms of coronavirus disease, without the need for hospitalization. The patient was treated at the tertiary medical center, four days after the onset of symptoms. During the hospitalization, he developed serious complications and fatal outcome. In this case, hypoxia-induced cardiac arrest was secondary to severe COVID-19 pneumonia with the development of acute respiratory distress syndrome and sepsis. Laboratory and flow cytometry results indicate the presence of the cytokine storm, while the mechanical ventilation might potentially increase the risk of lethal outcome.

This case report is important because it should give clinicians the insight into the treatment of the previously healthy individuals with COVID-19, especially in terms of possible laboratory markers that could indicate the presence of the cytokine storm phenomenon.
\end{abstract}

Keywords: COVID-19; coronavirus; epidemic; pandemic; ARDS; mechanical ventilation; cytokine storm.

\section{SAŽETAK}

COVID-19 je definisan kao respiratorna infekcija koja se širi kapljicama i neposrednim kontaktom sa zaraženom osobom. Prvi slučaj zaraze COVID-19 infekcije u Srbiji je prijavljen 6. marta 2020. godine.

U ovom radu, predstavljamo slučaj potvrđene infekcije COVID-19 kod prethodno zdravog čoveka, kod koga su preostala tri člana uže porodice pokazala blage simptome koronavirusne bolesti, bez potrebe za hospitalizacijom. Pacijent je lečen u tercijarnom medicinskom centru, četiri dana nakon pojave simptoma. Tokom hospitalizacije razvio je ozbiljne komplikacije i smrtni ishod. U ovom slučaju, srčani zastoj izazvan hipoksijom razvio se sekundarno, usled teškog oblika COVID-19 pneumonije i razvoja sindroma akutnog respiratornog distresa i sepse. Rezultati laboratorijske i flow citometrije ukazuju na prisustvo citokinske oluje, dok je mehanička ventilacija na kojoj je pacijent bio, takođe mogla da potencijalno poveća rizik od smrtnog ishoda.

Ovaj prikaz slučaja je važan jer treba da omogući kliničkim lekarima uvid u tretman prethodno zdravih pacijenata sa COVID19, posebno u smislu laboratorijskih markera koji mogu indikovati prisustvo fenomena citokinske oluje.

Ključne reči: COVID-19; korona virus; epidemija; pandemija; ARDS; mehanička ventilacija; citokinska oluja.
Corresponding author:

Valentina Opancina,

University of Kragujevac, Serbia, Faculty of Medical Sciences, Department of Radiology, Clinical Center "Kragujevac", Kragujevac, Serbia 


\section{INTRODUCTION}

After the onset of epidemic in China since December 2019, the World Health Organization labeled the severe acute respiratory syndrome coronavirus 2 (SARS-CoV-2) as the pandemic coronavirus disease 2019 (COVID-19) on February $11^{\text {th }}$, 2020 (1). COVID-19 is defined as a respiratory infection which is spread by droplets and immediate contact with an infected person $(2,3)$. SARS-CoV-2 is a new, previously unknown, RNA virus whose primary receptor is most likely angiotensin-converting enzyme 2 (3). The incubation period for this virus varies from 0 to 24 days, with the mean value of 5.2 days $(3,4,5)$. The reference standard for the diagnosis of this infection is done by the real-time reverse transcriptase polymerase chain reaction (rRT-PCR) assay (4). In addition to that, radiological imaging modalities are used, such as radiography and computed tomography $(3,5)$.

The first case of COVID-19 infection in Serbia was reported on March $6^{\text {th }}, 2020$. To this day, May $19^{\text {th }}, 10699$ Serbian citizens have a confirmed coronavirus disease with the rRT-PCR test, whereas there are 231 lethal cases and 4799 cured patients (6). COVID-19 mortality rate at this point in Serbia is $2.17 \%$ (6). The National Department of Health in Serbia approved the Handbook of COVID-19 prevention and treatment, written by the The First Affiliated Hospital, Zhejiang University School of Medicine in China, as the official handbook for coronavirus disease treatment (7).

Herein, we present the case of COVID-19 infection in a previously healthy man, with serious complications during the hospitalization and fatal outcome. Also, the route of coronavirus transmission is thoroughly explained, due to the fact that the patient was the only one of four family members who had a severe clinical manifestation of the infection and due to that, was hospitalized. The other three members, his wife and children had only mild symptoms and were isolated at home located in the central Serbia municipality. All four of them were non-smokers with regular physical activity and no comorbidities.

\section{CASE PRESENTATION}

A 25-year old man, a student and professional dancer from Serbia, experienced fatigue, fever $\left(38.2^{\circ} \mathrm{C}\right)$, anosmia and impaired sense of taste, on March $7^{\text {th }}, 2020$. The fever and fatigue lasted only for two days, while the other two symptoms lasted for the next 15 days. He is a professional athlete with no medical history and great health. He reported that he didn't have flu or flu-like symptoms in the last 15 years. On March $3^{\text {rd }}$ and $4^{\text {th }}$, he had a direct contact with his dancing coach, who was confirmed with COVID-19 infection with the rRT-PCR test, on March $12^{\text {th }}, 2020$. On March $9^{\text {th }}$, his 28-year old sister experienced the same symptoms as her brother, with a slightly higher fever $\left(38.8^{\circ} \mathrm{C}\right)$. She was home medicated with Paracetamol and Vitamin C. She is also a professional dancer and architect with no previous history of illness. The similar case was with their mother, 51-year old woman, an entrepreneur, who had a fever $\left(37.4^{\circ} \mathrm{C}\right)$ only on
March $10^{\text {th }}$, while anosmia and impaired sense of taste lasted for the next 15 days, just like in her children.

A 51-year old man, father of the family and an entrepreneur, developed a fever $\left(38.5^{\circ} \mathrm{C}\right)$, fatigue, myalgia, headache and abdominal pain, on March $10^{\text {th }}, 2020$. The patient had no previous medical history or any known chronic diseases. On March $12^{\text {th }}$, after his son got information that his coach was confirmed with COVID-19, he informed an epidemiologist by telephone call and got the instruction to isolate himself and in the case of progression of symptoms to come to the nearest tertiary medical facility. In the following day, his blood analysis at the local laboratory showed Lymphocytopenia $\left(1.2 \times 10^{9} / \mathrm{L}\right)$, while the other parameters were in normal range. In the next two days, he started dry coughing, developed bone tenderness and a recurrent fever from $38.5^{\circ} \mathrm{C}$ to $39^{\circ} \mathrm{C}$ which didn't respond well to the use of Paracetamol and Vitamin C combination. Due to this, the epidemiologist indicated an examination at the Clinical Center Kragujevac, by the on call infectologist on March $14^{\text {th }}$. The physical examination showed a fever $\left(38.4^{\circ} \mathrm{C}\right)$ and blood oxygen saturation (SPO2) $98 \%$. On the same day, late in the evening, the patient was admitted to the isolated area of the Clinic for Infectious Diseases, Clinical Center Kragujevac. Right after the admission, the patient was tested using the rRT-PCR, and the results came positive. After that point, he was under a constant supervision by trained medical staff and his treatment was according to the Handbook of COVID-19 prevention and treatment (6).

Body temperature fluctuations during the hospital stay are shown in Figure 1, whereas only values $\geq 37.5^{\circ} \mathrm{C}$ were presented, while on other days, the patient had a normal body temperature. Blood oxygen saturation is displayed in Figure 2. Laboratory blood results are shown in Table 1, divided by days of the hospitalization. Flow cytometry was done on the $25^{\text {th }}$ hospitalization day (Table 2), and prior to that, on the $4^{\text {th }}$ day, CD4 lymphocyte count was 999 cells/ $\mu$ l and CD8 lymphocyte count was 440 cells/ $\mu$ l, which was in normal range. Lymphocyte gating strategy in the whole human blood is presented in Figure 3.

The initial chest radiograph was done on the $2^{\text {nd }}$ day of hospitalization (Picture 1), which revealed ground-glass opacities perihilar and bilateral. On the $4^{\text {th }}$ day of hospitalization, the patient was sedated, intubated and mechanically ventilated, due to the worsening of the respiratory condition and decrease of SPO2 (Figure 2). A day later, there was a radiological progression in the lungs, with bilateral alveolar consolidation and presence of endotracheal tube (Picture 2). Three days after that, on the $8^{\text {th }}$ day of the hospital treatment, the patient was admitted to the Intensive care unit (ICU), specially organized for patients infected with coronavirus, on the account of illness intensification which can be well observed in Table 1. On the $16^{\text {th }}$ day, there was a radiological improvement comparing to the previous chest x-ray (CXR), endotracheal tube and central venous line were required (Picture 3). On the following day, which was the $17^{\text {th }}$ day of hospitalization, the patient was extubated, but his condition worsened 
and he was intubated on the $18^{\text {th }}$ day and mechanically ventilated again. On the same day, the bacteriological examination of tracheal aspirate was done and Acinetobacter spp was isolated, which confirmed the blood culture result, two days before. On the nineteenth day, lung radiography in Picture 4 showed radiological worsening with bilateral alveolar consolidation. On this day, laboratory results showed a noticeable rise in CRP (108.5), which was twice as higher comparing to the result on the $16^{\text {th }}$ day $(53.5 \mathrm{mg} / \mathrm{L})$. On the $21^{\text {st }}$ day of hospitalization, tracheotomy was performed. Two days later, CRP had its maximum value $(234.5 \mathrm{mg} / \mathrm{L})$ and CXR reported bilateral alveolar consolidation with panlobar affectation, the typical radiological findings of the acute respiratory distress syndrome (ARDS) (Picture 5). On the April $9^{\text {th }} 2020$, CXR showed presence of the subcutaneous emphysema. A thoracic surgeon was consulted and thoracic drainage was performed. Nevertheless, on the April $10^{\text {th }}$, which was the $27^{\text {th }}$ day of hospitalization, the patient's condition worsened, he was in bradycardia, hypotensive and SPO2 was $60 \%$. Even though intensive measures of resuscitation were performed, the patient underwent cardiac arrest and the outcome was lethal. Picture 6 shows final CXR with ARDS, subcutaneous emphysema, thoracic drains, MV and tracheotomy and central venous line. In this case, hypoxia-induced cardiac arrest was secondary to severe COVID-19 pneumonia with the development of ARDS and sepsis.

During the hospitalization, the patient was treated with a combined pharmacological treatment. The initial treatment included: antimalarial drug (Chloroquine phosphate, specific antiviral drug (Lopinavir-Ritonavir), antipyretic (Paracetamol), antibiotics (Ceftriaxone, Ertapenem, Azithromycin), vitamin $\mathrm{C}$ and intravenous fluids. Still, the progression of the disease required ICU care and the treatment was corrected, so the new antibiotic treatment included Piperacillin / Tazobactam and Tigecycline, while Colistin was added after the bacteriological examination of tracheal aspirate. In addition to that, due to the progression of illness, ICU treatment included: corticosteroid (Methylprednisolone), bronchodilators (Ipratropium bromide, Aminophylline), beta-blocker (Labetalol), calcium-channel blocker (Nifedipine), anticoagulant (Enoxaparin sodium), diuretic (Furosemide), vitamins (B1, D3), intravenous fluids, parenteral and enteral nutrition.

Picture 1. Initial chest radiography

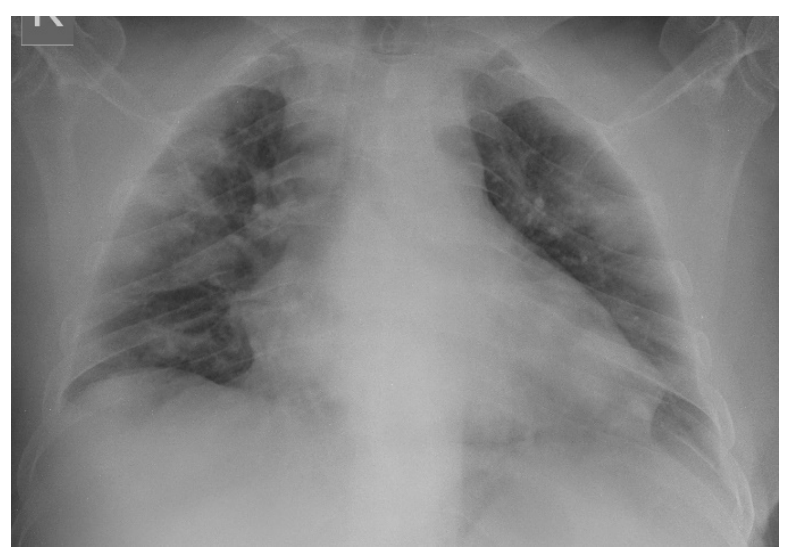

Picture 2. Chest radiography after the mechanical ventilation

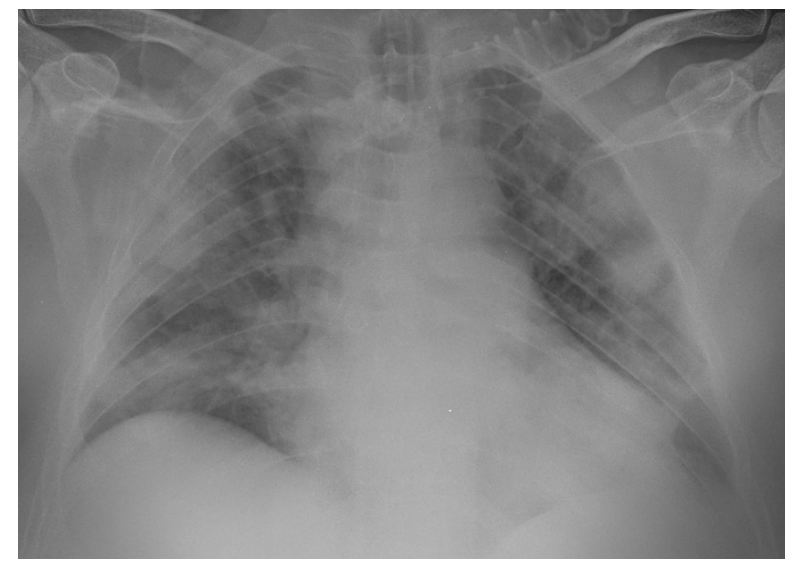

Picture 3. Chest radiography showing the improvement before extubation

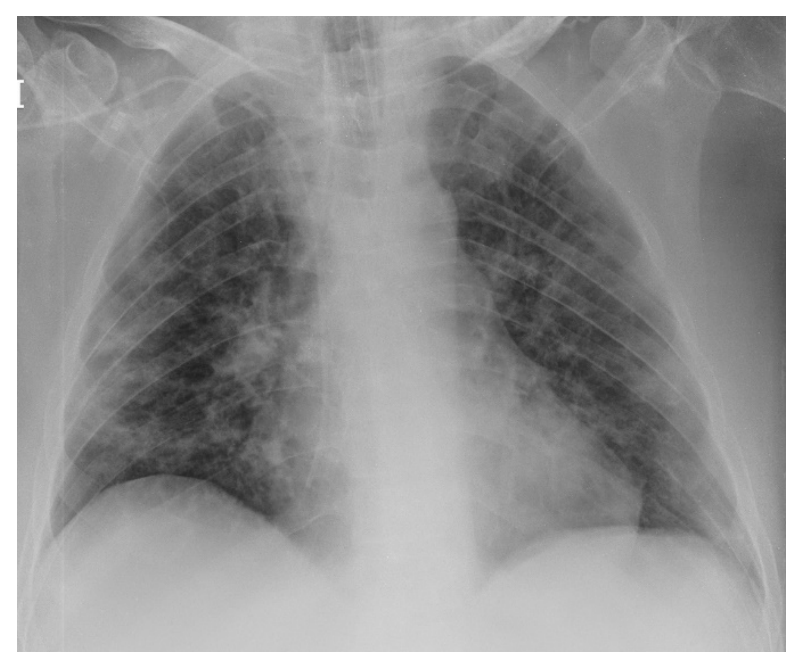

Picture 4. Chest radiography, patient is mechanically ventilated and CRP is critically rising

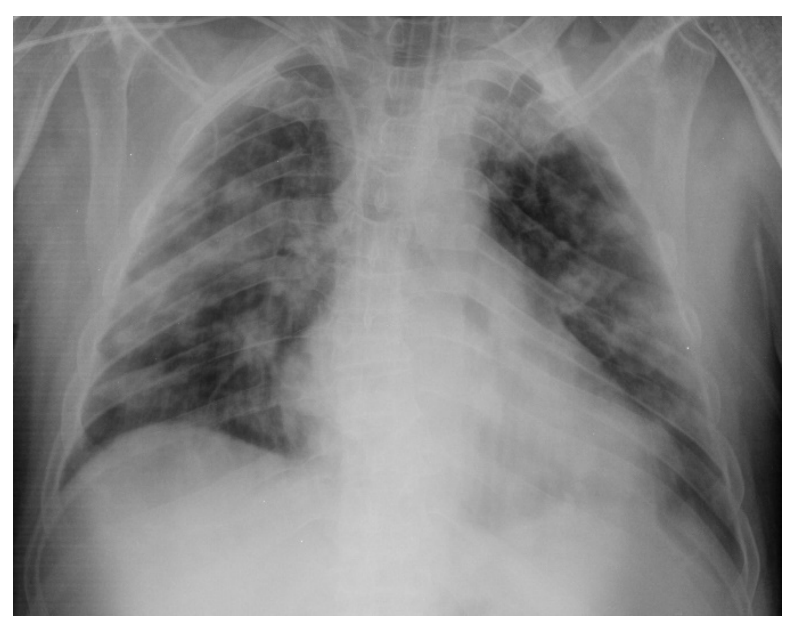


Picture 5. Chest radiography after tracheotomy, CRP is at max level on this day

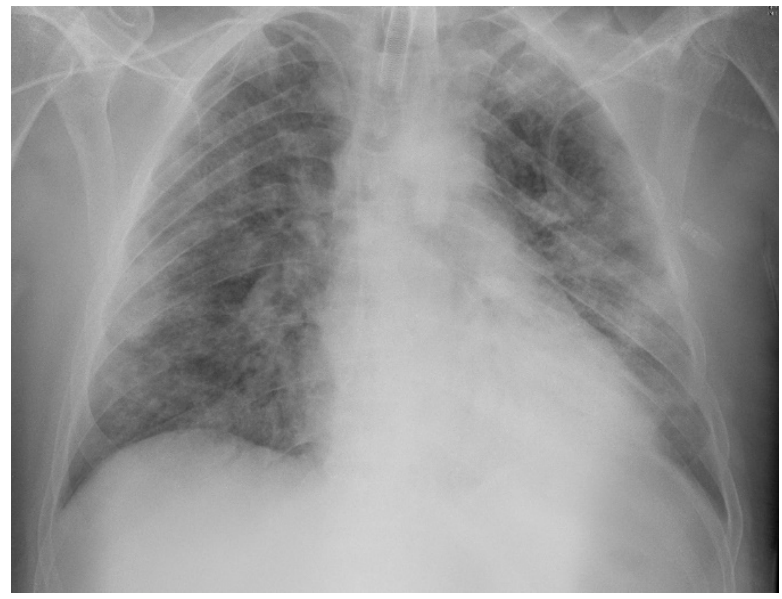

Picture 6. Final chest radiography before death

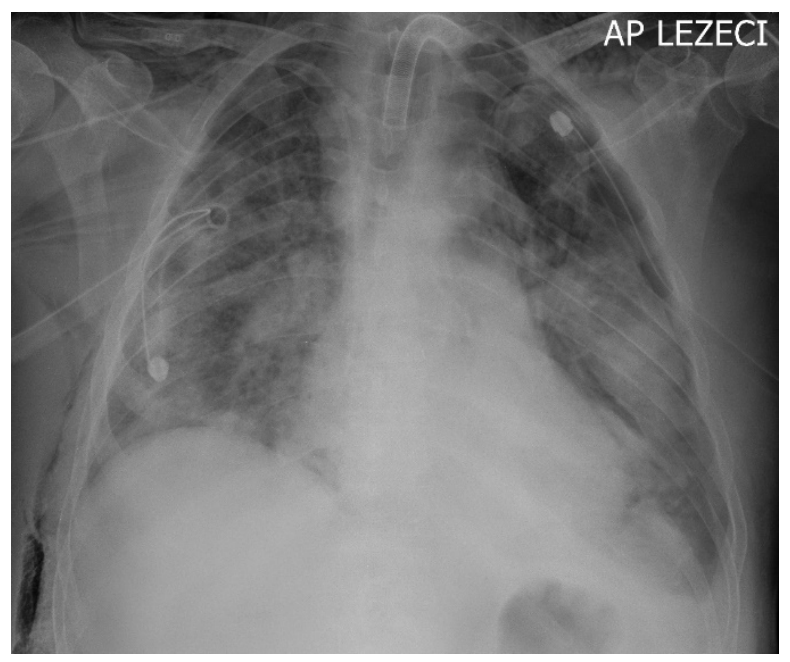

Figure 1. Body temperature fluctuations, recorded during each day of hospitalization

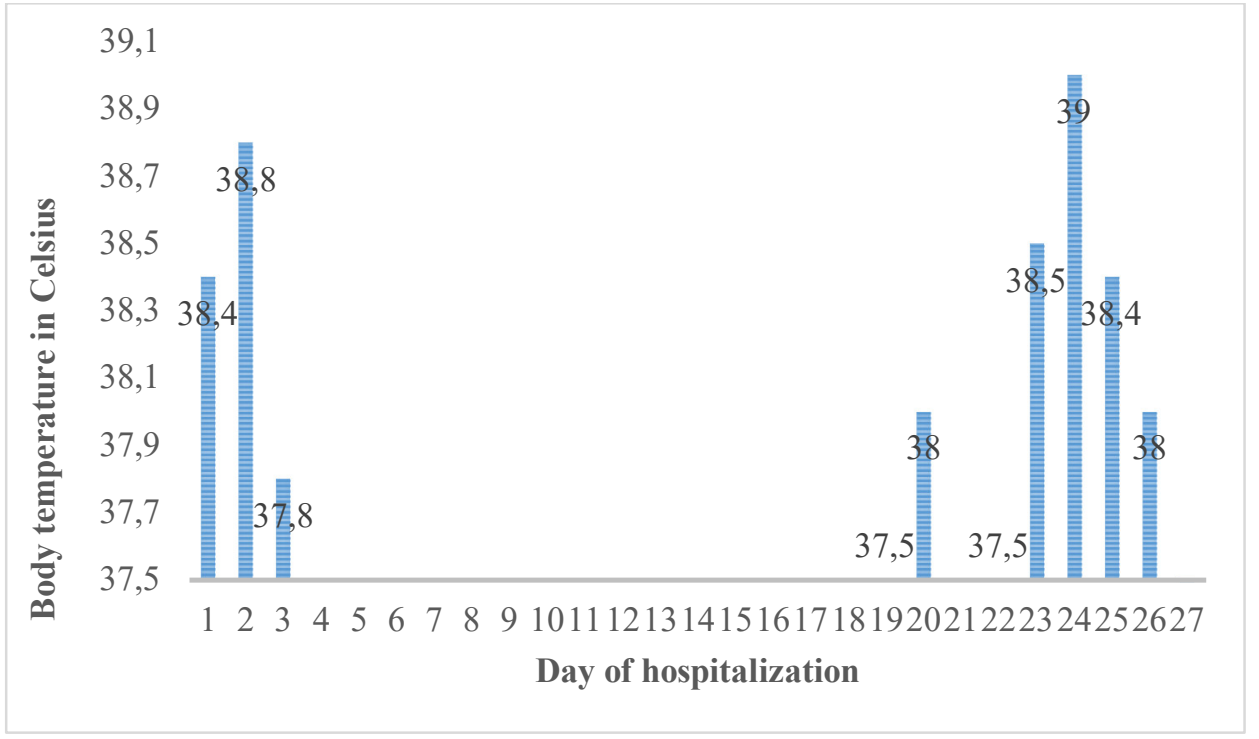

Figure 2. Blood oxygen saturation during each day of hospitalization

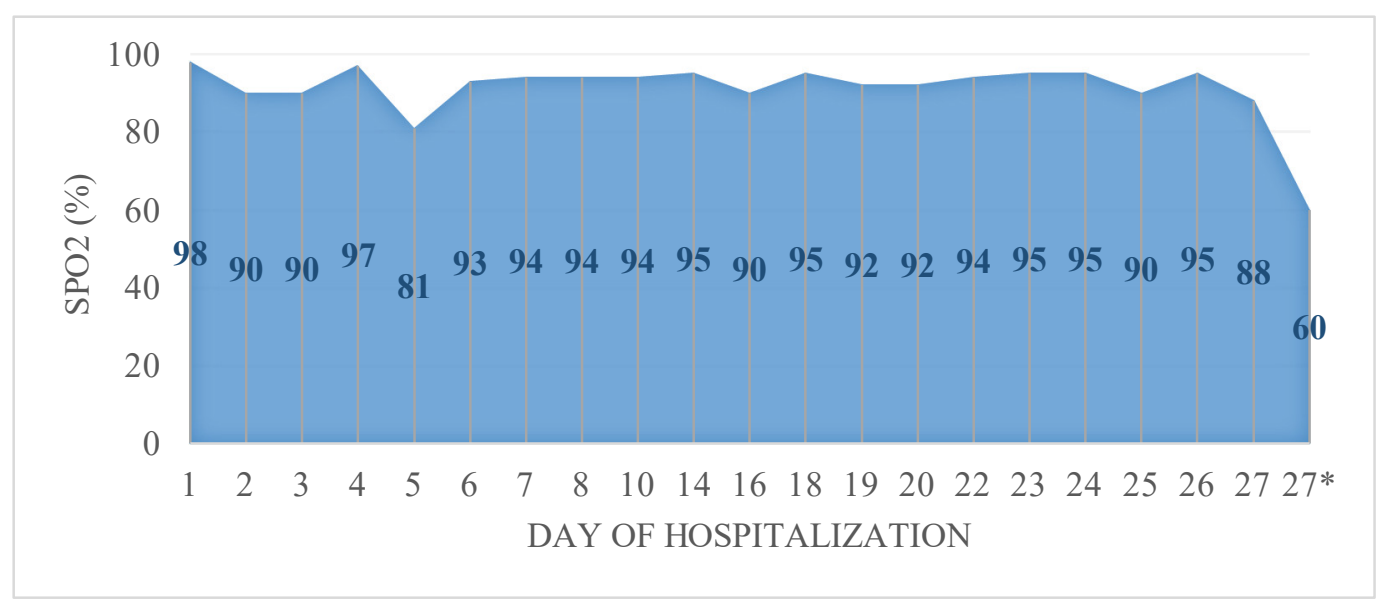

* On the 27th hospitalization day, SPO2 was recorded twice 
Figure 3. Lymphocyte gating strategy in whole human blood
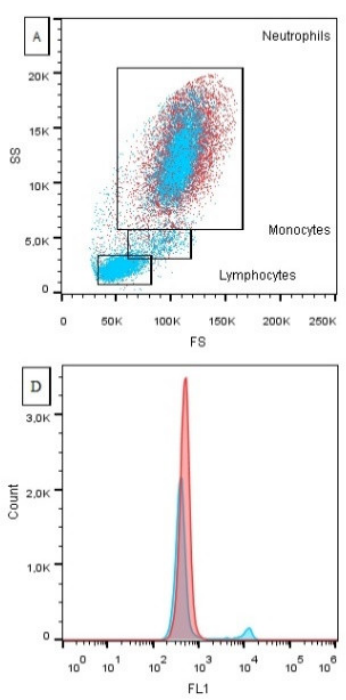
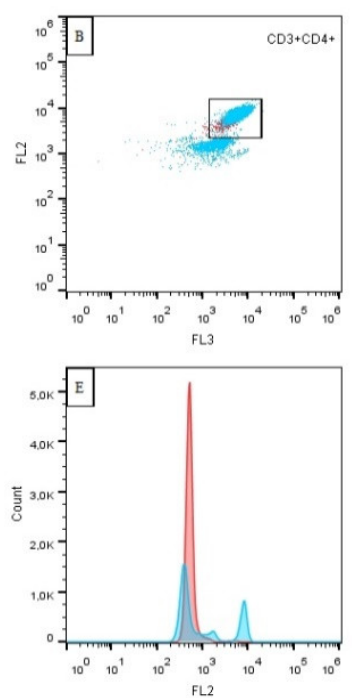
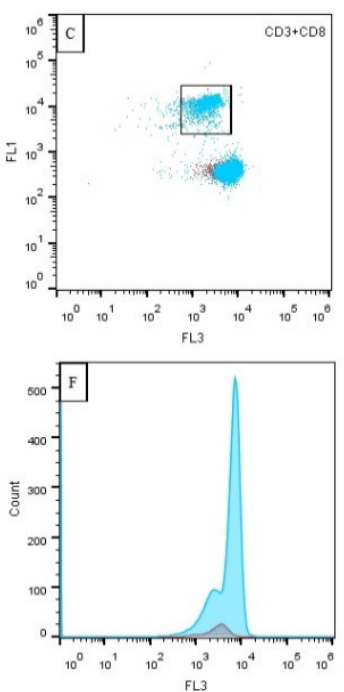

* (A) FSC vs. SSC plot: Broad selection of neutrophils, monocytes and lymphocytes based on their SSC/FSC properties. (B-C) Dot plots: Identification of CD3+CD4+ and CD3+CD8+ population after gating with color representing patient (red) and control (blue). (D-F) Smoothed histograms:

Lymphocyte FL1/CD8, FL2/CD4 and FL3/CD3 expression showing patient (red) and control (blue).

Table 1. Main laboratory findings

\begin{tabular}{|l|l|l|l|l|l|l|}
\hline & Reference range & Day $\mathbf{1}$ & \multicolumn{1}{l}{ Day 7} & Day $\mathbf{1 7}$ & Day 22 & Day 27 \\
\hline WBC & $3.7-10.0\left(10^{9} / \mathrm{L}\right)$ & 6.6 & $14.1 \uparrow$ & $22.59 \uparrow$ & $20.7 \uparrow$ & $12.25 \uparrow$ \\
\hline LYM & $1.2-3.4\left(10^{9} / \mathrm{L}\right)$ & 1.3 & $0.6 \downarrow$ & $0.58 \downarrow$ & & \\
\hline GRAN & $2.1-6.5\left(10^{9} / \mathrm{L}\right)$ & 4.4 & $12.4 \uparrow$ & $15.2 \uparrow$ & & \\
\hline RBC & $4.34-5.72\left(10^{12} / \mathrm{L}\right)$ & 5.1 & $4.17 \downarrow$ & $4.05 \downarrow$ & $3.61 \downarrow$ & $2.98 \downarrow$ \\
\hline HGB & $138-175(\mathrm{~g} / \mathrm{L})$ & 154 & $125 \downarrow$ & $123 \downarrow$ & $111 \downarrow$ & $91 \downarrow$ \\
\hline PLT & $135-450\left(10^{9} / \mathrm{L}\right)$ & 181 & 224 & 205 & $119 \downarrow$ & $134 \downarrow$ \\
\hline PT & $11.8-15.3(\mathrm{~s})$ & 13.2 & 13.9 & $17.7 \uparrow$ & $22.8 \uparrow$ & $38 \uparrow$ \\
\hline INR & $0.9-1.1$ & 0.97 & $1.22 \uparrow$ & $1.28 \uparrow$ & $1.63 \uparrow$ & $2.66 \uparrow$ \\
\hline PT\% & $70-120$ & 106 & $67 \downarrow$ & $64 \downarrow$ & $44 \downarrow$ & $23 \downarrow$ \\
\hline D-DIMER & $<0.50(\mathrm{ug} / \mathrm{ml} \mathrm{FEU})$ & 0.36 & $2.48 \uparrow$ & $2.22 \uparrow$ & $4.34 \uparrow$ & $72.2 \uparrow$ \\
\hline AST & $0-40(\mathrm{IU} / \mathrm{L})$ & 23 & $72 \uparrow$ & $44 \uparrow$ & $45 \uparrow$ & $59 \uparrow$ \\
\hline ALT & $0-40(\mathrm{IU} / \mathrm{L})$ & 22 & $82 \uparrow$ & $57 \uparrow$ & $56 \uparrow$ & $64 \uparrow$ \\
\hline GLUC & $3.8-6.1(\mathrm{mmol} / \mathrm{L})$ & 6.1 & $6.8 \uparrow$ & $7.7 \uparrow$ & $6.2 \uparrow$ & $6.9 \uparrow$ \\
\hline UREA & $3.0-8.0(\mathrm{mmol} / \mathrm{L})$ & 4.7 & 5.7 & 7.6 & $8.3 \uparrow$ & $16 \uparrow$ \\
\hline CREA & $49-106(\mathrm{mmol} / \mathrm{L})$ & 92 & 61 & 50 & $40 \downarrow$ & 71 \\
\hline CK & $0-171(\mathrm{U} / \mathrm{L})$ & $250 \uparrow$ & $686 \uparrow$ & 73 & $657 \uparrow$ & \\
\hline CK-MB & $<25.0(\mathrm{U} / \mathrm{L})$ & $26 \uparrow$ & 15 & 15 & 12 & \\
\hline CRP & $0.0-5.0(\mathrm{mg} / \mathrm{L})$ & $21.5 \uparrow$ & $86.4 \uparrow$ & $72.8 \uparrow$ & 189.8 & $203.7 \uparrow$ \\
\hline TROPONIN & $<0.0342(\mathrm{ng} / \mathrm{mL})$ & 0.0089 & 0.0237 & 0.0067 & $0.0409 \uparrow$ & \\
\hline Procalcitonin & $0.5-2.0$ & 0.143 & 0.05 & 0.113 & $2.16 \uparrow$ & 1.98 \\
\hline proBNP & $>2.0 \mathrm{risk}$ for sepsis(ng/mL) & 130 & 1496 & 443 & 591 & \\
\hline & negative $<125$, & & & & & \\
\hline & & 130 & & & & \\
\hline
\end{tabular}




\begin{tabular}{|l|l|l|l|l|l|l|}
\hline & Reference range & Day 1 & Day 7 & Day 17 & Day 22 & Day 27 \\
\hline & $\begin{array}{l}\text { grey area } 125-450, \\
\text { insufficiency }>450(\mathrm{pg} / \mathrm{mL})\end{array}$ & & & & & \\
\hline LDH & $220-450(\mathrm{U} / \mathrm{L})$ & 448 & $662 \uparrow$ & $706 \uparrow$ & & \\
\hline GGT & $7-50(\mathrm{IU} / \mathrm{L})$ & & 35 & $256 \uparrow$ & $61 \uparrow$ & $56 \uparrow$ \\
\hline Potassium & $3.5-5.3(\mathrm{mmol} / \mathrm{L})$ & 4 & 4.8 & 4.1 & 4.4 & $5.4 \uparrow$ \\
\hline Sodium & $137-147(\mathrm{mmol} / \mathrm{L})$ & $136 \downarrow$ & 137 & $135 \downarrow$ & 137 & $135 \downarrow$ \\
\hline Albumin & $35-52(\mathrm{~g} / \mathrm{L})$ & & $29 \downarrow$ & $27 \downarrow$ & $27 \downarrow$ & $27 \downarrow$ \\
\hline
\end{tabular}

* WBC-white blood cells, LYM-lymphocytes, GRAN- granulocytes, RBC-red blood cells, HGBhemoglobin, PLT- platelets, PT-prothrombin time, INR-international normalized ration, AST- aspartate aminotransferase, ALT- alanine transaminase, GLUC-glucose, CREA-creatinine, CK-creatin kinase, CRP-C reactive protein, proBNP-brain natriuretic peptide, LDH- lactate dehydrogenase, GGTgamma-glutamyl transferase, $\uparrow$-increased level, $\downarrow$-decreased level

Table 2. Flow cytometry

\begin{tabular}{|c|c|c|}
\hline & Observed values & Reference range \\
\hline Neutrophils CD15+ & 94.41 & $30-80 \%$ \\
\hline T lymphocytes CD3+ & 0.44 & $7-24 \%$ \\
\hline Helper T lymphocytes CD3+CD4+ & 0.40 & $4-20 \%$ \\
\hline Cytotoxic T lymphocytes CD3+CD8+ & 0.05 & $2-11 \%$ \\
\hline Monocytes CD14+ & 1.75 & $2-12 \%$ \\
\hline B lymphocytes CD19+ & 2.09 & $1-7 \%$ \\
\hline NK cells CD3-CD56+CD57- & 0.89 & $1-6 \%$ \\
\hline Activated NK cells CD3-CD56+CD57+ & 0.42 & \\
\hline Dendritic cells Lyn-HLADR+ & 0.51 & $0,3-0,9 \%$ \\
\hline Myeloid DC Lyn-HLADR+CD11c+ & 0.01 & \\
\hline Plasmacytoid DC Lyn-HLADR+CD123+ & 0.23 & \\
\hline $\mathrm{pDC} / \mathrm{mDC}$ & 20.92 & 3-9 \\
\hline $\mathrm{Ne} / \mathrm{Li}$ & 25.24 & $1-3$ \\
\hline
\end{tabular}

*DC-dendritic cells, pDC- Plasmacytoid dendritic cells, mDC- Myeloid dendritic cells,

$\mathrm{Ne} / \mathrm{Li}$ - neutrophil to lymphocyte ratio 


\section{DISCUSSION}

There are different explanations for the lethal outcome in this patient. The study on a large number of COVID-19 patients has shown that $76.4 \%$ patients $18-65$ years old, who were on the mechanical ventilation, have died, while the mortality rate of patients in the same age group, without MV, was $19.8 \%$ (8). Our patient was 408 hours mechanically ventilated during the hospitalization, which might potentially increase the risk of the fatal outcome. Also, it is hypothesized that the presence of multiple pathogens can influence the progression of the present viral respiratory infection, which was the case in this patient with Acinetobacter spp superinfection (9). Furthermore, it is important to pay attention to the fact that the other three family members of the presented patient had only mild symptoms even though all of them were infected by the same source, almost at the same time and none of them had history of previous diseases. The reason for that may lie in the genetic susceptibility, since there are papers that described similar outcome in blood-related family members $(10,11)$. It could be argued that the father was the only one with a specific genetic predisposition to this illness, while children and their mother had similar genetic predisposition and thus similar clinical presentation and good outcome. Finally, the outcome may be the result of the cytokine storm which is observed in COVID-19 patients and not easy to treat (12). It is described that the cytokine storm contributes to the severity of COVID-19 infection, but more importantly, depletion of CD8+ lymphocytes and high levels of CRP and D-dimer were marked as important markers (13). In our patients, there were noticeable high levels of CRP and Ddimer, as well as the lower count of CD8+ lymphocytes, which confirms the suspicion of the cytokine storm presence and its influence on the outcome.

\section{CONCLUSION}

COVID-19 is an unpredictable pandemic infection with possible serious complications such as severe pneumonia, ARDS and death. Further studies are needed to explain the mechanisms that lead to the progression of the disease and its complications, in order to prevent them. More importantly, this case report should give clinicians the insight into the treatment of healthy individuals with COVID-19, especially in terms of possible laboratory markers that could indicate the presence of the cytokine storm phenomenon.

\section{ACKNOWLEDGMENTS}

The authors thank the family of the deceased patient for their consent and help in acquiring the necessary data.

\section{REFERENCES}

1. World Health Organization. World experts and funders set priorities for COVID-19 research. Available online: https://www.who.int/news-room/detail/12-02-2020world-experts-and-funders-set-priorities-for-covid-19research

2. Guan WJ, Ni ZY, Hu Y, Liang WH, Ou CQ, He JX, et al. Clinical Characteristics of Coronavirus Disease 2019 in China. N Engl J Med 2020; 382(18):1708-1720. doi:10.1056/NEJMoa2002032.

3. Milovanović DR, Janković SM, Ružić Zečević D, Folić M, Rosić N, Jovanović D et al. Lečenje koronavirusne bolesti (COVID-19). Medicinski časopis 2020; 54(1). DOI: https://doi.org/10.5937/mckg54-25981. [Online First]

4. Zhu N, Zhang D, Wang W, Li X, Yang B, Song J et al. A Novel Coronavirus from Patients with Pneumonia in China, 2019. N Engl J Med 2020; 382(8):727-733.

5. Deng Z, Hu Y, Yang P, et al. Diagnosis and treatment of an acute severe pneumonia patient with COVID-19: Case report [published online ahead of print, $2020 \mathrm{Mar}$ 30]. J Med Virol 2020;10.1002/jmv.25802. doi:10.1002/jmv.25802

6. Korona virus COVID-19. Available online: https://covid19.rs

7. The First Affiliated Hospital, Zhejiang University School of Medicine. (2020). Handbook of COVID-19 Prevention and Treatment. Jack Ma Foundation and Alibaba Foundation.

8. Richardson S, Hirsch JS, Narasimhan M, Crawford JM, McGinn T, Davidson KWet al. Presenting Characteristics, Comorbidities, and Outcomes Among 5700 Patients Hospitalized With COVID-19 in the New York City Area. JAMA 2020. doi: 10.1001/jama.2020.6775. [Epub ahead of print]

9. Edrada EM, Lopez EB, Villarama JB, Salva Villarama EP, Dagoc BF, Smith C et al. First COVID-19 infections in the Philippines: a case report. Trop Med Health 2020;48:21.

10. Yousefzadegan S, Rezaei N. Case Report: Death Due to Novel Coronavirus Disease (COVID-19) in Three Brothers. Am J Trop Med Hyg 2020. doi: 10.4269/ajtmh.20-0240. [Epub ahead of print]

11. Chen S, Yin Q, Shi H, et al. A familial cluster, including a kidney transplant recipient, of Coronavirus Disease 2019 (COVID-19) in Wuhan, China. Am J Transplant 2020;20(7):1869-1874. doi:10.1111/ajt.15903

12. Douedi S, Miskoff J. Novel coronavirus 2019 (COVID19): A case report and review of treatments. Medicine (Baltimore) 2020;99(19):e20207.

13. Kuppalli K, Rasmussen AL. A glimpse into the eye of the COVID-19 cytokine storm. EBioMedicine 2020;55:102789. doi: 10.1016/j.ebiom.2020.102789. [Epub ahead of print] 